\title{
JURISDICCIÓN ESTATAL Y ECLESIÁSTICA EN LOS ABUSOS SEXUALES CONTRA MENORES EN CHILE
}

STATE AND ECCLESIASTICAL JURISDICTION IN SEXUAL ABUSE AGAINST CHILDREN IN CHILE

\section{INFORME EN DERECHO}

\begin{tabular}{|c|c|}
\hline CÓMO CITAR ESTE ARTÍCULO (CHICAGO) & $\begin{array}{l}\text { Cortínez Castro, René. "Jurisdicción es- } \\
\text { tatal y eclesiástica en los abusos sexua- } \\
\text { les contra menores en Chile". Revista de } \\
\text { Derecho Aplicado LLM UC } 4 \text { (2019). } \\
\text { doi: } 10.776 / \text { rda.0.4.27I8 }\end{array}$ \\
\hline
\end{tabular}

REVISTA DE DERECHO APLICADO LLM UC Número 4

Diciembre 20I9

ISSN: $245^{2-4344}$ 


\section{Resumen}

El texto es una versión abreviada del informe en derecho solicitado al autor sobre los efectos que tendría el secreto pontificio en la investigación y sanción de delitos en contra de menores de edad por parte de los Tribunales Ordinarios de Justicia. Comienza estableciendo la personalidad jurídica de derecho público que el Estado de Chile reconoce a la Iglesia católica, emanada de la Constitución de 1980. Fundamenta esta afirmación también en los actos jurídicos de los órganos del Estado, que de modo uniforme tienen como presupuesto la referida personalidad jurídica. Del análisis de la Ley 19.638 se concluye que no solo no ha alterado el referido estatus, sino que lo refuerza y desarrolla aspectos de la libertad religiosa no tratados explícitamente en la Carta Fundamental, como el reconocimiento del derecho propio de las confesiones religiosas. En cuanto al secreto pontificio, presenta la complejidad de la regulación canónica, así como las diferencias entre esta y la práctica de las autoridades eclesiásticas. Concluye señalando que el Estado de Chile, en los casos de abuso sexual de menores, puede requerir la información de que disponen los tribunales eclesiásticos, en conformidad con la propia legislación canónica y del derecho internacional.

Palabras clave: Abuso sexual de menores, delicta graviora, relaciones IglesiaEstado, libertad religiosa, jurisdicción eclesiástica, secreto pontificio.

\section{Abstract}

The text is an abbreviated version of the report in law requested from the author on the effects that papal secrecy would have in the investigation and punishment of crimes against minors by the Ordinary Courts of Justice. It begins by establishing the legal personality of public law that de State of Chile recognizes to the Catholic Church, which emanates from the 1980 Constitution. It also bases this assertion on the legal acts of the State organs, which in a uniform way have the referred legal personality. From the analysis of Law 19,638 , we conclude that not only it has not altered the aforementioned status, but that it reinforces it and develops aspects of religious freedom not explicitly addressed in the Fundamental Charter, such as the recognition of the right of religious confessions. As for the pontifical secret, it presents the complexity of canonical regulation, as well as the differences between it and the practice of ecclesiastical authorities. It concludes by pointing out the legitimate field of action of the State of Chile in cases of child's sexual abuse.

Keywords: Sexual abuse of minors, criminal offense, Church-State relations, religious freedom, ecclesiastical jurisdiction, pontifical secret. 


\section{René Cortínez Castro}

Universidad Alberto Hurtado

Santiago, Chile

rcortine@uahurtado.cl

Universidad Alberto Hurtado

Santiago, Chile

rcortine@uahurtado.cl
René Cortínez Castro es abogado, licenciado en Derecho y magíster en Derecho Público con mención en Derecho Constitucional por la Pontificia Universidad Católica de Chile. Profesor de Derecho Público en la Facultad de Derecho de la Universidad Alberto Hurtado.

René Cortínez Castro is a lawyer with a degree in Law and Master in Public Law with a mention in Constitutional Law from the Pontifical Catholic University of Chile. Professor of Public Law at the Faculty of Law of the Alberto Hurtado University. 


\section{INFORME EN DERECHO}

Se nos ha solicitado responder la siguiente consulta: ¿Qué limitaciones - si las hubiere- impondría el régimen jurídico de la Iglesia católica en Chile a las diligencias de investigación que lleva a cabo el Ministerio Público y las actuaciones de los Tribunales de Justicia, preexistente y subsistente a la entrada en vigor de la Ley 19.638? ¿Hay dos regímenes jurídicos que coexisten?

Para dar respuesta a esta interrogante, analizaremos el estatuto jurídico de la Iglesia católica en el derecho público chileno, así como la recepción de su derecho interno ${ }^{1}$.

A continuación, estudiaremos el efecto que cabe atribuir a la Ley 19.638 de 1998 en las dos dimensiones antes mencionadas.

Presentaremos, como complemento, la doctrina, jurisprudencia y práctica administrativa que avalan nuestra interpretación.

El secreto pontificio será examinado para determinar sus características, en especial las alternativas que ofrece de cara a la colaboración entre la jurisdicción civil y la eclesiástica.

Cerramos el análisis consignando los últimos documentos eclesiales, el de la Santa Sede y a nivel local, que comprometen a la Iglesia católica en la investigación, sanción y reparación de las víctimas de abusos sexuales cometidos por clérigos.

Finalmente, señalamos nuestras conclusiones y algunas sugerencias prudenciales para avanzar en el tema materia del informe.

\section{PERSONALIDAD JURÍDICA DE LA IGLESIA CATÓLICA}

El reconocimiento de la personalidad jurídica de derecho público de la Iglesia católica, y de su ordenamiento jurídico, no es un "privilegio", sino una consecuencia de las características de dicha Iglesia.

La Iǵlesia católica, desde el punto de vista jurídico, presenta características particulares que la diferencian de otras Iglesias: posee un ordenamiento jurídico autónomo, reconocido universalmente, que es público y que puede ser probado frente a terceros; su jerarquía es visible y conocida, y la suprema autoridad, el Romano Pontífice (Santa Sede) goza de

1 Por razones de extensión se ha suprimido lo relativo a la historia constitucional y el derecho internacional de los derechos humanos. 
personalidad jurídica de derecho internacional, ampliamente reconocida por los Estados; y su organización es pública y conocida, tanto en su estructura como en las competencias de sus autoridades, entre otras.

\section{I.I. Constitución Política de la República de I980}

Transcurridos cincuenta años desde la promulgación de la Constitución de 1925, durante los trabajos de redacción de la Constitución de 1980 surgió en la Comisión de Estudios de la Nueva Constitución (Comisión Ortúzar) la cuestión de la personalidad jurídica de la Iglesia católica, y se agregó la preocupación por el estatuto aplicable a las demás Iglesias, estimándose que no podían existir situaciones de privilegio que vulneraran el principio de igualdad.

Así, en la comisión se sostuvo que no podía discriminarse en materia de personalidad jurídica de las Iglesias y, con acuerdo de la mayoría de sus miembros, se estampó en actas una constancia en el sentido de que todas las Iglesias gozaban de personalidad jurídica de derecho público, bastando que la autoridad les reconociera el carácter de tales. Tratándose de la Iglesia católica, se afirmó que este reconocimiento había sido hecho por el propio constituyente de 1925: "La Comisión resuelve aprobar este precepto (se refiere al texto que correspondía al artículo 10 numeral 2 de la Carta de 1925) sin modificaciones, en atención a que él es el producto de un acuerdo adoptado en su oportunidad entre el Gobierno de Chile y la Santa Sede. [...] todas las Iglesias y confesiones religiosas tienen personalidad jurídica de derecho público [...] Tratándose, sin embargo, de la Iglesia católica, este reconocimiento ha sido hecho por el propio constituyente de 1925" (sesión 132, del 23 de junio de 1975)².

\section{I.2. El acuerdo con la Santa Sede}

Refiriéndose a este acuerdo, el profesor Jorge Precht Pizarro afirma:

No cabe duda alguna de que entre el Estado de Chile y la Santa Sede existió un concordato substancialmente hablando, si bien formalmente no existió un documento separado llamado concordato. Ello, por lo demás, se hizo a petición del Gobierno de Chile debido a la situación política interna del país, que exigía pronta promulgación de una nueva Constitución. Tal acuerdo internacional entre la Santa Sede y el Gobierno de la República de Chile es un compromiso de honor y sería una afrenta atroz que el hecho de haber sido pedido y obtenido su no escritura

2 "La Comisión resuelve aprobar este precepto sin modificaciones, en atención a que él es el producto de un acuerdo adoptado en su oportunidad entre el Gobierno de Chile y la Santa Sede" (páginas 2 y 3). Las cursivas en esta y las próximas citas son nuestras. 
con un concordato formal se tornara contra la mano que en difíciles momentos se tendiera a Chile y a su presidente [Alessandri Palma] para alcanzar la paz interna, como en 1978 lo fuera para lograr la paz exterior de la República”’.

Bajo la nueva Constitución, se mantuvo en la práctica el estatus de la Iglesia católica, esto es, el reconocimiento de su personalidad jurídica de derecho público.

\section{I.3. La doctrina}

El profesor de derecho público Jorge Precht Pizarro sostiene en sus publicaciones ${ }^{4}$ y conferencias que, conforme con la Constitución de 1980 y su legislación complementaria, la Iglesia católica apostólica romana goza de personalidad jurídica de derecho público, a la que el ordenamiento jurídico reconoce, además, la potestad de crear otras personas jurídicas: "La Iglesia católica, bajo el régimen de tres constituciones (1833, 1925 y 1980), es en Chile una persona jurídica de derecho público. Si bien en la Constitución actual no existe una declaración formal en el texto, la Comisión de Estudios de la Nueva Constitución formuló una expresa nota en ese sentido, la que forma parte de la historia fidedigna de la Constitución”.

En su opinión, en el derecho chileno se produce la recepción de la institución "Iglesia católica apostólica romana”, tal como ella es, conforme al derecho canónico e internacional:

La Iglesia católica es anterior al Estado como unidad política en Occidente y es consecuencialmente anterior al Estado de Chile. Lo que ha hecho el Estado de Chile bajo tres constituciones es reconocer esa realidad jurídica que lo antecede y que en cierto sentido ha plasmado la comunidad nacional chilena y el propio Estado. Asimismo, ha reconocido a la Santa Sede como persona jurídica en el plano de las relaciones internacionales, explícitamente en 1833, más explícitamente en 1925 y veladamente en 1980. [...] La Iglesia católica - y las instituciones nacidas en su seno- se incorporan al derecho interno chileno sin mutación de su naturaleza, sino tal como se encuentran en el propio derecho canónico ${ }^{6}$.

3 Informe del profesor Precht durante la discusión de la Ley I9.638, incluido en el Anexo del Informe, sobre el proyecto de ley, de la Comisión de Constitución del Senado (I998).

4 Jorge Precht Pizarro, "La personalidad jurídica de la Iglesia católica y de los entes eclesiásticos católicos ante el derecho del Estado de Chile". Revista Chilena de Derecho i6, n. ${ }^{\circ} 3$ (septiembre-diciembre I989): $683-723$.

$5 \quad$ Ibid., 723.

$6 \quad$ Ibid., 695-696. 
Alejandro Silva Bascuñán, desde que publicara su Tratado de derecho constitucional en 1963, y luego como miembro de la Comisión de Estudio de la Nueva Constitución ${ }^{7}$, ha sostenido que la Iglesia católica goza, en nuestro país, de personalidad jurídica de derecho público.

\section{LA LEY I9.638, SOBRE LA CONSTITUCIÓN JURÍDICA DE LAS IGLESIAS Y ORGANIZACIONES RELIGIOSAS ${ }^{8}$}

El estatuto jurídico de las confesiones religiosas distintas de la Iglesia católica, después de la Constitución de 1925, había sido motivo de diversas gestiones para su modificación. Al menos oficialmente, conocemos las siguientes:

En un comienzo los textos redactados que fueron conocidos en borrador solo se referían a las Iglesias evangélicas. El plazo fijado para el funcionamiento de la comisión expiró sin que se conociera públicamente el resultado de su trabajo.

El 26 de octubre de 1993, el presidente Aylwin envió a la Cámara de Diputados un proyecto de ley, "Proyecto de ley sobre normas acerca de la constitución jurídica y funcionamiento de las Iglesias y organizaciones religiosas", que la hacía aplicable a todas las Iglesias, no solo a las evangélicas.

Sin embargo, excluía expresamente a la Iglesia católica de la aplicación de sus normas, en los términos siguientes: "Las normas de esta ley no serán aplicables a las personas jurídicas a que se refiere el inciso segundo del artículo 547 del Código Civil".

Durante la discusión de la ley, el texto aprobado por la Cámara de Diputados mantuvo la exclusión de la Iglesia católica, no expresamente como en el proyecto Aylwin, sino que como consecuencia del reconocimiento de su personalidad jurídica, en los términos siguientes: "El Estado reconoce la personalidad jurídica y la plena capacidad de obrar de las entidades religiosas que gocen de ella a la fecha de entrada en vigencia de esta ley".

El Senado constituyó una Comisión Especial para el estudio del proyecto ley, y el 25 de agosto de 1997 emitió un segundo informe con el que concluía su cometido, en el cual proponía modificaciones al proyecto que había sido aprobado en la Cámara de Diputados.

7 Sus opiniones durante la redacción de la Constitución de ig80 pueden verse en las sesiones de la Comisión, que han sido resumidas y citadas al tratar, en esta tesis, de la historia fidedigna del artículo ig numeral 6 de la Constitución Política de ig80.

8 Las normas estatales que recogen la preceptiva canónica o regulan ámbitos propios de la Iglesia católica pueden verse en René Cortínez Castro (coordinador), Ana María Celis Brunet y María Elena Pimstein Scroggie, Derecho eclesiástico chileno: Normas concordadas y comentadas (Santiago: Ediciones UC, 2010). 
Según se desprende de la lectura de este informe, en un primer momento se aprobó reponer la exclusión expresa de la Iglesia católica en el proyecto de ley, según los términos originalmente propuestos por el presidente Aylwin; pero, finalmente, la Comisión Especial optó por modificar el texto aprobado por la Cámara de Diputados.

El texto aprobado decía: "Artículo 6: El Estado reconoce el ordenamiento, la personalidad jurídica y la plena capacidad de goce y ejercicio de las Iglesias, confesiones e instituciones religiosas que los tengan a la fecha de publicación de esta ley, entidades que mantendrán el régimen jurídico adquirido con anterioridad a ella”.

El 2 de septiembre de 1998, después de algo menos de un año de trabajo, la Comisión de Constitución del Senado concluyó su informe modificando el texto aprobado por la Comisión Especial, con el objeto de perfeccionar la redacción de algunas de sus disposiciones, y "en el espíritu de subsanar las razonables dudas de constitucionalidad surgidas durante el debate de este proyecto".

Entre las modificaciones introducidas se encuentra la nueva redacción del artículo 6, que como el artículo 20, expresaba: "El Estado reconoce el ordenamiento, la personalidad jurídica de derecho público y la plena capacidad de goce y ejercicio de las Iglesias, confesiones e instituciones religiosas que los tengan a la fecha de publicación de esta ley, entidades que mantendrán el régimen jurídico que les es propio. Las Iglesias, confesiones e instituciones religiosas que se constituyan con posterioridad a la entrada en vigencia de la presente ley, se regirán por ésta. Las actualmente existentes podrán optar, en cualquier momento, por someterse a las disposiciones de esta ley".

La disposición transcrita subsanaba, de manera imperfecta, los reparos formulados al texto anterior, reconociendo que la Iglesia católica goza de personalidad jurídica de derecho público y que se rige por su propio ordenamiento jurídico.

El martes 16 de julio de 1999, finalmente, el Senado tuvo ocasión de pronunciarse respecto del proyecto de ley.

La Sala del Senado se veía enfrentada a tener que votar entre el artículo 6 aprobado por la Comisión Especial y el nuevo artículo 20 propuesto por su Comisión de Constitución, lo que significaba optar entre las demandas de grupos evangélicos y las prevenciones de constitucionalidad presentadas, además de oponer entre sí a los senadores que habían integrado las dos comisiones redactoras.

La solución se obtuvo por medio de la presentación de una indicación, suscrita por la unanimidad de los comités, que modificaba el artículo 20 del texto redactado en la Comisión de Constitución del Senado, en los términos siguientes: "El Estado reconoce la 
personalidad jurídica, sea esta de derecho público o de derecho privado, el ordenamiento y la plena capacidad de goce y ejercicio de las Iglesias, confesiones e instituciones religiosas que los tengan a la fecha de publicación de esta ley, entidades que mantendrán el régimen jurídico que les es propio, sin que ello sea causa de trato desigual entre dichas entidades y las que se constituyan en conformidad a la presente ley".

El texto aprobado por el Senado debía ser sometido a la Cámara de Diputados, en su calidad de cámara de origen. Ello ocurrió el 15 de julio del mismo año, aprobándose por 85 votos a favor, sin votos en contra ni abstenciones, entre otras disposiciones el artículo siguiente:

Disposición final. Artículo 20: El Estado reconoce el ordenamiento, la personalidad jurídica, sea ésta de derecho público o de derecho privado, y la plena capacidad de goce y ejercicio de las Iglesias, confesiones e instituciones religiosas que los tengan a la fecha de publicación de esta ley, entidades que mantendrán el régimen jurídico que les es propio, sin que ello sea causa de trato desigual entre dichas entidades y las que se constituyan en conformidad a esta ley.

Resultaría muy extenso exponer aquí, en forma íntegra, la historia fidedigna de la ley para fundamentar la opinión del suscrito, más allá del esbozo presentado. Es por esto que precisaremos algunos puntos.

La discusión iniciada en 1993 concluyó recién en 1998 con la publicación del texto aprobado. Elemento central del largo debate fue el estatuto jurídico de la Iglesia católica, ya que algunas Iǵlesias, apoyadas por parlamentarios de todos los sectores políticos, aspiraban a un igualitarismo absoluto de todas.

En nuestra opinión, el artículo 20 de la Ley 19.638 fue producto de una transacción para evitar el rechazo de la Iglesia católica y un posible requerimiento al Tribunal Constitucional, lo que habría prolongado la tensión del debate y puesto en riesgo el apoyo de los votantes para no pocos parlamentarios. Así se explica la frase "el Estado reconoce el ordenamiento, la personalidad jurídica, sea esta de derecho público o de derecho privado, y la plena capacidad de goce y ejercicio de las Iglesias, confesiones e instituciones religiosas que los tengan a la fecha de publicación de esta ley".

En efecto, sólo la Iglesia católica apostólica romana y la arquidiócesis católica apostólica ortodoxa de Chile ${ }^{9}$ eran reconocidas como personas jurídicas de derecho público en 1998, y esto con total claridad. ¿Por qué no se dijo esto de forma expresa, aunque fuese a mero título ejemplar? Por la oposición de los sectores evangélicos, que desarrollaron un agresivo lobby en el Congreso Nacional a la mención de la Iglesia católica.

9 La Ley 17.725 de 1972 concedió personalidad jurídica a la arquidiócesis católica apostólica ortodoxa de Chile. 
Esta opinión es compartida por el profesor de la Universidad de Talca, Jorge del Picó: "Esta norma, como se desprende de su lectura, traduce fielmente el propósito del legislador de no afectar los derechos adquiridos por las entidades religiosas que, al momento de la publicación de la Ley 19.638, ya gozaban de la calidad de personas jurídicas de derecho público. Se procuró, en definitiva, no alterar el reconocimiento de la personalidad jurídica y de la capacidad de goce y de ejercicio de la Iglesia católica y de la Iglesia ortodoxa, asumiendo la existencia de la tutela constitucional respectiva, consagrada en el artículo 19 numeral 24 de la CPR”.

La deferencia del legislador tuvo plena justificación, toda vez que uno de los puntos expuestos en el debate y que dilató la aprobación de la ley en el Congreso fue el temor expresado por algunos parlamentarios, pertenecientes a distintos partidos políticos con representación en el Congreso Nacional, a que la nueva ley pudiera afectar la situación jurídica vigente tanto de la Iglesia católica como de la Iglesia ortodoxa.

En concreto, la cuestión debatida se zanjó en la primera redacción propuesta para el artículo 6 de la ley en tramitación, el cual afectaba los derechos adquiridos de ambas Iglesias, al no reconocer de un modo adecuado con la realidad histórica el origen y el carácter de la personalidad jurídica que ya poseían en propiedad.

La oposición a un reconocimiento expreso se manifestó, en forma abierta y frontal, por parte de los representantes de las Iǵlesias evangélicas, los que vieron en ella un intento por preservar privilegios incompatibles con el principio de igualdad ante la ley. La resistencia ofrecida por estos sectores retrasó la aprobación del proyecto por al menos dos años, pero finalmente primó la voluntad de entendimiento y la ley incorporó una norma de compromiso en el artículo 20 del proyecto, con una redacción que, a la vez que cauteló los derechos adquiridos de las Iglesias históricas, consagró que tal reconocimiento no podía ser causa de un trato desigual entre las entidades antiguas y las constituidas en conformidad a la nueva ley. Con la inclusión de esta normativa, la ley pudo ser aprobada de forma unánime, con el concurso de parlamentarios de los diversos partidos políticos ${ }^{10}$.

\section{LA PERSONALIDAD JURÍdica DE LA IGLESIA CATÓLICA DESPUÉS DE LA LEY I9.638}

La recepción o reconocimiento de la personalidad jurídica de derecho público de la Iglesia católica consagrada en la Constitución de 1980, en opinión del informante, no ha sido sino reiterada en esta ley.

10 Cfr. Jorge del Picó Rubio, "Régimen especial de reconocimiento de la personalidad jurídica de derecho público en la Ley I9.638: Marco legal aplicable a las Iglesias católica y ortodoxa”. Ius et Praxis I8, n. ${ }^{\circ}$ I (2012): 37-60, doi: 10.4067/So718-00I220I2000I00003. 
Consideramos que el artículo 20 de la Ley 19.638 reafirma dicho reconocimiento y, además, en razón de la proscripción de toda discriminación arbitraria entre las confesiones religiosas, formula un reconocimiento explícito del derecho propio y de otras dimensiones eclesiales.

Sin perjuicio de algunas opiniones en contrario, en la práctica los órganos del Estado han reconocido la existencia de la Iglesia católica, su personalidad jurídica de derecho público y la aplicación de su derecho propio.

En particular, como se dirá más adelante, este reconocimiento comprende también los procesos investigativos y sancionatorios en materia administrativa o penal (petición de antecedentes a obispos, exhortos a la Santa Sede, pronunciamientos jurisdiccionales a causa de recursos de amparo y protección, etcétera).

El informante es del parecer que la ley en comento no ha modificado en modo alguno el estatuto jurídico de la Iglesia católica, anterior a su publicación, sino más bien reforzado el estatus vigente y explicitado algunos aspectos propios de la libertad religiosa como derecho fundamental reconocido en el artículo 19 numeral 6 de la Constitución de 1980.

La proscripción constitucional de toda discriminación arbitraria se repite en la Ley 19.638, de manera que todos los derechos que se reconocen en dicho cuerpo legal favorecen por igual a todas las Igglesias y, por lo tanto, también a la católica (cfr. capítulos I, II, IV, V).

\section{I. Actos jurídicos de la Administración del Estado}

Como decíamos, existen numerosos ejemplos de actos jurídicos de los órganos del Estado que manifiestan el reconocimiento de la personalidad jurídica y estatus de la Iglesia católica ${ }^{11}$.

Así, se autorizan colectas públicas para financiar servicios prestados por personas jurídicas canónicas en favor de los más necesitados ${ }^{12}$, o bien la pesca de investigación por parte de establecimientos de enseñanza superior ${ }^{13}$. También se otorgan concesiones de

11 Para un catálogo exhaustivo desde 2006 al presente, puede verse el Boletín Jurídico del Observatorio de Libertad Religiosa en América Latina y El Caribe, del Centro UC Derecho y Religión, disponible en http://derechoyreligion.uc.cl/es/boletin-juridico/2org.

12 Resolución Exenta 556, de 2018, publicada en el Diario Oficial del 26 de junio de 20I8, en favor de Fundación Solidaria Trabajo para un Hermano, persona jurídica canónica erigida por el arzobispado de Santiago.

13 Pontificia Universidad Católica de Valparaíso (persona jurídica canónica): Resolución r.5², del Ministerio de Economía, Fomento y Turismo, Subsecretaría de Pesca y Acuicultura, del I3 de junio de 20I3, autoriza a la Pontificia Universidad Católica de Valparaíso a efectuar una pesca de investigación de conformidad con los términos técnicos de en la comuna de San Antonio. 
radiodifusión o de derechos de aguas en favor de estas mismas entidades. Se las emplaza, como parte, en juicios de diversa naturaleza, y reconoce como titulares del derecho de propiedad sobre inmuebles, para efectos de su expropiación ${ }^{14}$ o declaratoria de monumento histórico ${ }^{15}$.

En el ámbito de los derechos fundamentales se les reconoce la objeción de conciencia institucional ${ }^{16} \mathrm{o}$ bien se impone a los ministros de culto católicos la obligación de denunciar delitos en contra de menores de edad o adultos vulnerables ${ }^{17}$.

\subsection{Jurisprudencia judicial: Situaciones en que los tribunales reconocen la persona- lidad jurídica y el ordenamiento interno que rige a las personas jurídicas canónicas}

En sentencia del 26 de diciembre de 2014, en autos caratulados Estado de Chile con Congregación Religiosa Legionarios de Cristo (rol 3169-2010), el Decimotercer Juzgado Civil de Santiago acogió la acción de reparación de daño ambiental y condenó a la parte demandada.

Recientemente, el proyecto de una empresa hidroeléctrica en el sector del Cajón del Maipo ha dado lugar a diversos procesos judiciales y administrativos promovidos por las religiosas del Monasterio del Amor Misericordioso y de la Virgen del Carmen (carmelitas descalzas).

En los mencionados procesos no solo se ha reconocido la personalidad jurídica del monasterio, sino también el reconocimiento y aplicación de la legislación canónica respectiva.

14 Por Decreto MOP (Exento) 898, del in de agosto de 20I7, se expropiaron los lotes de terreno que figuran a nombre de Vicariato Apostólico de la Ara.

15 Ministerio de Educación, Decreto 76 de 20I7, Declara Monumento Nacional en la categoría de Monumento Histórico a la Iglesia San Martín de Tours de Chapoco, ubicada en la comuna de General Lagos, provincia de Parinacota, región de Arica y Parinacota, publicada en el Diario Oficial el i7 de mayo de 2017 .

16 Ministerio de Salud, Objeción de conciencia institucional, Resolución Exenta 028502 del 6 de diciembre de 20I8, UC Christus Servicios Clínicos SpA, recuperado el 20 de diciembre de 2018 de http://ojs.uc.cl/index.php/bjur/article/view/r7og.

17 Boletín Ir768-o7 de 20I8, Moción de ley que modifica el Código Procesal Penal para imponer a las autoridades religiosas o eclesiásticas que indica la obligación de denunciar hechos que revistieren caracteres de delito contra menores de edad y personas impedidas de ejercer con autonomía sus derechos, y de que tomaren conocimiento en virtud de sus funciones. 
El tema en discusión fue el reconocimiento y efectos de la "clausura papal" de los monasterios religiosos, respecto de las limitaciones al dominio, al punto que el tribunal pidió un informe en derecho sobre la legislación eclesial.

3.2.I. Juicios de indemnización, por abuso sexual de clérigos, en contra de la diócesis a la que pertenecían: Reconocimiento de la personalidad jurídica y el derecho propio

José Andrés Aguirre. Su condena penal fue seguida de una demanda en contra del arzobispado de Santiago por la responsabilidad extracontractual que le cabría al obispo diocesano, de quien dependía el clérigo sancionado ${ }^{18}$.

La sentencia de término, en lo que interesa a este informe ${ }^{19}$, señala lo siguiente:

$\left.36 .^{\circ}\right)$ En rigor, esas cuestiones son básicamente dos. De las cuales la segunda presenta, a su vez, dos subinterrogantes [sic], a saber: a) ¿Cuál es el ordenamiento jurídico que rige las relaciones entre el obispo y uno de los integrantes del respectivo clero diocesano? b) ¿Son las referidas relaciones de una naturaleza tal que generen responsabilidad civil del obispo por los hechos en que incurran los integrantes del clero diocesano con arreglo a lo preceptuado en los artículos 2.320 y 2.322 del Código Civil? Lo cual implica, a su vez, examinar las siguientes dos alternativas: a) ${ }_{2}$ Pueden las relaciones entre el obispo y el sacerdote subsumirse directa e inmediatamente en lo dispuesto por los preceptos antes referidos? b) De no ser así, ̨pueden las disposiciones de las normas mentadas ser extendidas mediante interpretación analógica o accediendo a un supraprincipio [sic] general del derecho del cual, por así decirlo, los artículos 2.320 y 2.322 del Código Civil no serían sino expresiones legislativas ejemplares pero no taxativas o, por el contrario, ha de concluirse que los preceptos mencionados contienen una casuística taxativa, no susceptible de ampliación por el intérprete?

37. ${ }^{\circ}$ Q Que, en cuanto concierne a la primera de las cuestiones formuladas, la respuesta ha de encontrarse, como la propia sentencia impugnada lo reconoce indirectamente, en lo preceptuado por el artículo 547 del Código Civil, con arreglo al cual las disposiciones del título XXXIII del libro I, sobre las personas jurídicas no se extienden "a las corporaciones o fundaciones de derecho público, como la nación, el fisco, las municipalidades, las iglesias, las comunidades religiosas y los establecimientos que se costean con fondos del erario: estas corporaciones y fundaciones se rigen por leyes y reglamentos especiales”. El fallo entiende, poniendo

18 Sentencia de la Corte Suprema, rol 3640-04, 5 de enero de 2005 .

19 La demanda por responsabilidad extracontractual fue acogida en primera instancia y finalmente rechazada por el máximo tribunal. 
en relación la disposición recién citada con el artículo 20 de la Ley 19.638, que ella "se refiere únicamente al título XXIII del libro I del Código Civil, es decir, constitución, organización interna, forma y causales de disolución de personas jurídicas y no con una presunta dispensa de la aplicación del ordenamiento jurídico nacional", (considerando decimoquinto, letra b), para concluir que la relación existente entre los obispos y los sacerdotes "tiene caracteres civiles" (considerando vigésimo segundo). Este razonamiento, sin embargo, descansa sobre una contradicción flagrante, pues si la "organización interna" de la iglesia se rige, como lo estipula el artículo 20 de la Ley 19.638 por el "régimen jurídico que le es propio", entonces la relación entre sus distintos integrantes está precisamente regulada por ese ordenamiento propio, el cual, por consiguiente, no "tiene caracteres civiles" como erradamente concluye el fallador.

38. $\left.{ }^{\circ}\right)$ Que, en efecto, con arreglo al Diccionario de la Real Academia, "organización” quiere decir tanto como "acción y efecto de organizar u organizarse" (primera acepción) o bien, en sentido figurado, "disposición, arreglo, orden". A su vez, "organizar" aparece definido, en la única acepción que puede convenir a nuestro asunto, como "establecer o reformar una cosa, sujetando a reglas el número, orden, armonía y dependencia de las partes que la componen o que han de componerla”. Por consiguiente, puesto que el obispo y los sacerdotes son "parte" de la Iglesia católica, ello significa que las normas que la organizan son las que deciden sobre el "orden, armonía y dependencia" en que se encuentran y, por ello, la sentencia atacada no podía, sin contradecirse, sostener que el artículo 20 de la Ley 19.638 se refiere a la "organización interna" de dicha iglesia, para luego concluir inexplicablemente que la relación existente entre los obispos y los sacerdotes "tiene caracteres civiles".

$\left.39 .^{\circ}\right)$ Que, con todo, lo expuesto no significa afirmar definitivamente que la mentada relación entre el obispo y sus sacerdotes diocesanos sea tal que excluya sin más la responsabilidad civil de aquel por los hechos de estos. Para llegar a una conclusión de esa clase, en efecto, es preciso indagar si la vinculación en comento es susceptible de ser comprendida por las normas contenidas en los artículos 2.320 y 2.322 del Código Civil, sea porque, como se adelantó, lo dispuesto en ellos le es aplicable de forma directa, sea porque, no siéndolo, puede de todas maneras aplicársele por vía analógica.

$\left.51 .^{\circ}\right)$ Que, con lo razonado en las consideraciones que anteceden, queda demostrado que el vínculo existente entre el obispo y los sacerdotes de sus diócesis, tal como se encuentra regulado en el derecho canónico que lo rige, no es semejante a aquellos a que se refieren los artículos 2.320 y 2.322 del Código Civil y sobre los cuales éste hace descansar la responsabilidad civil por el hecho de un tercero. 
Caso Karadima. En este caso, con posterioridad al sobreseimiento por prescripción de la acción penal ante los tribunales del Estado, el clérigo fue condenado en sede canónica. No obstante, la acuciosa investigación permitió establecer su responsabilidad, por lo que las víctimas demandaron indemnización de perjuicios en contra del arzobispado de Santiago como responsable del hecho ajeno.

Así, la sentencia dictada por el ministro de fuero el 16 de marzo de 2017 (rol 9.209-2012) no objeta la personalidad jurídica de la Iglesia católica o de la arquidiócesis de Santiago de Chile, ni la aplicación del derecho canónico para determinar la naturaleza de la relación entre el obispo diocesano y el presbítero Karadima. Tampoco fue objetada la jurisdicción eclesial para los casos de abusos sexuales a menores cometidos por miembros de la jerarquía de la Iglesia católica.

Caso Precht Bañados (amparo). La acción cautelar señala responsable al cardenal arzobispo de Santiago, quien en forma arbitraria y violando sus garantías constitucionales le habría impuesto, como medida cautelar, al presbítero individualizado la obligación de residir en la ciudad de Santiago, perturbando de esta manera su libertad personal.

En sentencia de primera instancia de la Corte de Apelaciones de Santiago del 30 de agosto de 2018 (rol 21.992-18), el tribunal no se declara incompetente ni formula cuestión alguna sobre la peculiaridad de la materia sometida a su conocimiento. Termina rechazando la acción al considerar que no existe una decisión jurídica de la autoridad eclesiástica que ordene al amparado permanecer en Santiago, sin ser suficiente un comunicado público (de contenido erróneo) en el sitio web oficial de la diócesis para afectar su libertad personal.

La Corte no cuestiona la personalidad jurídica de la arquidiócesis de Santiago ni la aplicación del derecho canónico, y menos aún la actividad jurisdiccional que tiene lugar respecto del recurrente:

Funda su petición en que no existe orden judicial alguna expedida contra del amparado, por alguna autoridad judicial del fuero civil, que perturbe por causa o motivo alguno, que dicha medida emana del fuero eclesiástico al que pertenece el amparado, siendo abiertamente atentatoria contra su libertad personal [...] se le impuso al amparado, en el marco de un proceso canónico disciplinario que se sigue en su contra, entre otras medidas cautelares, la de residir obligatoriamente en la ciudad de Santiago mientras dure el proceso canónico.

La recurrida, en su oportunidad, expuso:

Recuerda que el amparado es sacerdote de la Iglesia Católica, por su voluntad; que conoce no solo de la teología o la moral, sino que de las disposiciones que rigen a la Iglesia católica, de modo que no puede desconocer los derechos y obligaciones que el estado sacerdotal le confiere e impone, ni alegar que asumió sin su consentimiento. 
En ese sentido - expone-que existiendo antecedentes suficientes para decretar una investigación por posible delito canónico, se instruyó proceso y que entre las facultades cautelares del obispo diocesano conforme al canon 1.722 del Código de Derecho Canónico, se encuentra "imponerle o prohibirle la residencia en un lugar o territorio”, encontrándose las penas que arriesgan los procesados definidas por el canon 1.312 del citado cuerpo normativo la prohibición o mandato de residir en un determinado territorio. Hace presente que, al no poseer facultad de imperio, quedará el cumplimiento de la medida a la obediencia libre y voluntaria del afectado, por lo que resulta falso que se está forzando al amparado a residir en la ciudad de Santiago".

La Corte Suprema ${ }^{20}$, conociendo de la apelación, revoca la resolución apelada ${ }^{21}$ y, en su lugar, acoge el recurso de amparo interpuesto a favor del presbítero y ordena que la recurrida elimine de inmediato la comunicación pública, además de que "cese en cualquier acto que afecte ilegalmente la libertad personal del amparado. Comuníquese lo resuelto al arzobispado de Santiago y a la Conferencia Episcopal de Chile por la vía más rápida”.

Es decir, solo difiere del tribunal de primera instancia en cuanto a que el comunicado en el sitio web (que carece de fundamento jurídico) sí afectaría al recurrido, en cuanto "lo coloca en la imposibilidad moral de trasladarse fuera de los límites de la capital" (considerando primero).

En efecto, el tribunal considera que

tal situación, desde un punto de vista jurídico, es constitutiva de un actuar ilícito por parte de la recurrida que amenaza y perturba la libertad personal del amparado, por cuanto se ve expuesto a una orden - expresada en un medio público-que lo conmina perentoriamente a restringir su libre desplazamiento, cuestión que es capaz de generar en él un fundado temor de ser objeto de coerción, consistente en la imposición de graves sanciones morales en caso de incumplimiento, todo ello justificado en un comunicado que no tiene correlato con la investigación canónica que lo afecta y con las decisiones adoptadas a raíz de la misma (considerando tercero).

Este razonamiento supone reconocer valor a las decisiones de la autoridad eclesiástica, de modo que, al no haber sido decretada una medida dentro del proceso, la información publicada en la web carece de fundamento.

20 Corte Suprema, rol 2I.992-I8, 6 de septiembre de 20I7.

21 Resolución del 30 de agosto de 20I8, dictada por la Corte de Apelaciones de Santiago en el Ingreso Corte I. $785^{-2018}$. 
Caso Precht (recurso de protección) ${ }^{22}$.

El recurrente por sí [sic] y en favor de Cristian Precht Bañados, deduce la acción de protección constitucional en contra del arzobispado de Santiago, representada por el cardenal y arzobispo de Santiago Ricardo Ezzati Andrello, por haber incurrido en el acto arbitrario e ilegal de seguir irregularmente una investigación previa en contra del protegido, afectando las garantías constitucionales contempladas en los numerales 1, 2, 3 y 4 del artículo 19 de la Carta Fundamental, por lo que solicitó se acoja el recurso, declarando que la recurrida ha vulnerado todas o alguna de las garantías antes anotadas, por lo que resolvió anular el procedimiento de investigación previa, seguido bajo el rol 103-2018, y para el evento de que tales antecedentes hubieren sido enviados al Vaticano en la Santa Sede, sea solicitada su devolución para efectos de si le parece a la recurrida instruir una nueva investigación previa de cargo de un sacerdote distinto a David Albornoz Pavicic.

Expresa, con el carácter de preliminar, que esta Corte no puede sustraerse del conocimiento del asunto que se expondrá, desde que debe tenerse en consideración que no existe otra autoridad de carácter civil llamada a restablecer el imperio del derecho ${ }^{23}$. Que [...] el ciudadano Precht ha sido sustraído del derecho nacional interno, quedando sometido arbitrariamente a decisiones de un ente persecutor eclesiástico que incluso ha decretado medidas cautelares o prohibiciones. Manifiesta que en la causa seguida ante la recurrida, han sido vulnerados los derechos básicos que le asisten a todo imputado ${ }^{24}$.

La decisión de la Corte resulta particularmente ilustrativa, por lo que nos permitimos reproducir varios de sus considerandos a continuación:

Cuarto: Que nuestra Carta Fundamental reconoce la personalidad jurídica del arzobispado de Santiago, la que se valida como de derecho público en la Constitución de 1833, por pertenecer a la Iglesia como un organismo con individualidad y personalidad propias. Calidad refrendada en el Código Civil en su artículo 547 inciso segundo, en el que expresamente señala a las Iglesias y comunidades religiosas, entre otras, como entidades de derecho público, previniendo que se rigen por leyes y reglamentos especiales. Así reconocida la libertad de las Iglesias para establecer sus propios estatutos a fin de organizar sus actividades propias, como lo son el culto, el magisterio y jurisdicción, regulación que encuentra sus bases en el derecho canónico, normas meramente eclesiásticas que se encuentran contenidas en

\footnotetext{
22 Sentencia de la Corte de Apelaciones de Santiago, rol 59.6r7-2018, 30 de agosto de 2018.

23 Cfr. página I de la sentencia.

24 Cfr. página 3 de la sentencia.
} 
el Código Canónico, las que obligan a los bautizados en la Iglesia católica y a quienes han sido recibidos en ella, como lo previene el numeral 11 del título I, De las Leyes Eclesiásticas, reconociendo la potestad de régimen ordinaria o de jurisdicción, al llamado ordinario, en su título VIII, numeral 134, entendiéndose por tal, además del romano pontífice, a los obispos diocesanos y a todos aquellos que aun interinamente han sido nombrados para regir una iglesia particular o una comunidad a ella equiparada, así como también a quienes en ellas tienen potestad ejecutiva ordinaria, esto es, los vicarios generales y episcopales, los superiores mayores de institutos religiosos clericales de derecho pontificio y de sociedades clericales de vida apostólica de derecho pontificio, que tienen al menos potestad ejecutiva. Y su parte I, De los Fieles Cristianos, capítulo III, De las Obligaciones y Derechos de los Clérigos, en su numeral 273, dispone que los clérigos tienen especial obligación de mostrar respeto y obediencia al sumo pontífice y a su ordinario propio. En su libro VII establece la potestad de la Iglesia para juzgar con derecho propio y exclusivo las causas que se refieren a cosas espirituales o anexas a ella, y de violación de las leyes eclesiásticas y de todo aquello que contenga razón de pecado, en lo que se refiere a la determinación de la culpa y a la imposición de penas eclesiásticas, reglando el proceso y desarrollo del mismo, al que se somete dicho juzgamiento, el que se inicia con la investigación previa, siempre que el ordinario tenga noticia verosímil de un delito.

Quinto: Que al recurrente Precht, como miembro del orden sacerdotal de la Iglesia católica, no le son desconocidas las reglas canónicas a las que se encuentra sometido en razón de dicho estatus, las que informan sus derechos y obligaciones, así como las sanciones a su inobservancia, y procedimientos para hacerlas efectivas, las que ha debido estudiar a profundidad para recibir la orden eclesiástica.

Sexto: Que la investigación previa realizada por el arzobispado de Santiago, lo ha sido conforme las facultades otorgadas por la ley canónica, en procedimiento establecido en el Código Canónico, por la autoridad eclesial competente, conforme la calidad de sacerdote del protegido.

Séptimo: Que conforme la normativa legal reseñada, en la que se funda la decisión de la autoridad, y los antecedentes que la motivan, no es posible determinar que el proceso de investigación previa, llevado por el arzobispado de Santiago en el que se adoptaron las medidas cautelares respecto del recurrente, hubiere vulnerado las garantías constitucionales del debido proceso e igualdad ante la ley, por tratarse de un órgano que lo ha llevado adelante en el ejercicio de su jurisdicción reconocida constitucionalmente, en una instancia preliminar, la que garantiza en sus preceptos canónicos la oportunidad en la que el ordinario, conforme al mérito de tal investigación, decrete el inicio del proceso en que se fijará la oportunidad de los descargos del acusado, como así lo informa la recurrida. 
Octavo: Que la aplicación del proceso canónico no es óbice para que además obre la justicia ordinaria frente a hechos que revisten el carácter de delito, la que ha de aplicarse por los tribunales con jurisdicción penal a través de la investigación correspondiente llevada por el Ministerio Público, entre otros, respecto del recurrente, como se ha hecho públicamente conocido a través de los medios periodísticos y televisivos, noticia que ha dado inicio a la investigación canónica -cuestionada en este recurso-, la que asimismo le es inherente en su calidad de miembro del orden clerical, procedimiento que no vulnera la normativa constitucional, como ya se ha relacionado.

Noveno: Que la vulneración a la salud psíquica y la honra que se denuncian, el recurrente la relaciona como una consecuencia directa de haber sido procesado por un órgano - al que desconoce toda legalidad-, lo que le habría provocado la afectación a su salud y buen nombre, dada la connotación pública que de ello se ha hecho, a través de los medios de comunicación; sin embargo, la acción ejercida por la justicia canónica no puede considerarse como un trato vejatorio ni vulneratorio a los derechos constitucionales garantizados por los números 1 y 4 del artículo 19 de la Constitución Política de la República, por cuanto en dicho proceso, -al igual que aquel seguido en sede penal ordinaria-, se busca precisamente investigar y determinar la efectividad de las denuncias de hechos en que se sindica como culpable al señor Precht, de acuerdo a un régimen legalmente reconocido.

Décimo: Que lo relacionado resulta bastante para determinar que el acto de la autoridad motivo de esta acción constitucional no resulta ilegal ni arbitrario, al no afectar los derechos protegidos en los numerales 1, 2, 3 y 4 del artículo 19 de la Constitución Política de la República, dado que conforme la reglamentación institucional a la que se encuentra sujeto el recurrente resguarda su derecho al debido proceso, de acuerdo se dispone en la normativa contemplada en el Código Canónico. Por estas consideraciones, y de acuerdo a lo preceptuado en los artículos 19 y 20 de la Constitución Política de la República, y auto acordado de la Excelentísima Corte Suprema pertinente a la materia, se rechaza, en todas sus partes, el recurso de protección deducido en esta causa, por don Luciano Fouillioux Fernández, en favor de don Cristian Precht Bañados.

\section{ACTIVIDAD JURISDICCIONAL DE LA IGLESIA CATÓLICA RESPECTO DE LA COMI- SIÓN DE ABUSOS SEXUALES POR CLÉRIGOS}

En los números anteriores, particularmente lo relativo a los procesos contra clérigos por abuso sexual, queda de manifiesto que los Tribunales de Justicia de Chile reconocen que la actividad jurisdiccional eclesiástica es reconocida no solo al interno de una confesión religiosa, sino también ante el ordenamiento del Estado, tanto es así que incluso se han abocado a revisar su cumplimiento y efectos, de cara a la protección de los derechos fundamentales de las personas. 


\section{I. El Secreto pontificio}

El documento más relevante en la materia es el Rescriptum ex audientia instructio de secreto pontificio ${ }^{25}$. A continuación, consignamos una caracterización canónica del mismo, en los aspectos relevantes para este informe.

Imperatividad jurídica y su defensa. La ley reguladora del secreto pontificio ha engrosado el acervo normativo del ordenamiento jurídico de la sociedad eclesiástica. Se trata de una ley ordinaria de derecho común con carácter universal y, por tanto, vinculante en toda la Iǵlesia, que regula ex integro una materia jurídica concreta. Por eso, no solo establece las normas dispositivas, sino que también señala la dinámica defensiva que se utilizará para garantizar su eficacia en caso de incumplimiento. La ley es explícita al especificar el doble tipo de sanción que la protege: la sanción disciplinar y la sanción penal ${ }^{26}$.

Es "suficiente para incurrir en la sanción administrativa la violación, aunque no sea dolosa ni gravemente culposa, de la norma administrativa. Dicha sanción no pretende castigar un delito ni enmendar al delincuente, sino defender la eficacia operativa del oficio. De ahí que la sanción disciplinar, si en la norma no se dice lo contrario, sea aplicable aunque el destinatario demuestre su falta de culpabilidad grave en la violación” ${ }^{27}$.

En cuanto a la sanción penal. "Las cuestiones sometidas al secreto pontificio son de tal importancia para la buena marcha de la vida social de la Iglesia, que la manifestación extemporánea de las mismas perjudicaría gravemente el bien común eclesial. De ahí que la observancia del secreto pontificio constituya un interés social fundamental exigitivo de una protección penal contra quienes lo violen culpablemente" ${ }^{28}$.

Determinado el destinatario de la norma penal canónica, vemos que la ley lo abarca en su máxima amplitud: todo aquel que tenga noticia del secreto pontificio, sea que la haya adquirido por razón del cargo, por encomienda especial, o por cualquier otro cauce lícito o ilícito ${ }^{29}$.

25 Acta Apostolicae Sedis Commentarium Officiale, volumen LXVI, Typis Polyglottis Vaticanis, I974, p. 89. Cfr. traducción al español de la Universidad de Navarra. Recuperado el i6 de diciembre de 2018 de http://www.vatican.va/roman_curia/secretariat_state/card-villot/documents/rc_seg-st_I9710204_secreta-continere_lt.html.

26 Juan Arias, "Las normas sobre el secreto pontificio: Sistema de defensa". Ius Canonicum I 4 , n. 28 (I974): 332-352. Recuperado de http://dadun.unav.edu/handle/IoI7I/I 766 .

27 Ibid., 339 .

28 Ibidem.

29 Ibid., $34^{2}$. 
La tipificación del delito está, pues, en esta ley reducido a su mínima expresión, por lo que quedan prácticamente sin conseguir los objetivos propios de la tipificación. Aparece sin duda que el interés protegido por la ley es grave, pero no se determina hasta dónde llega su gravedad. El interés jurídico aparece protegido, aunque creemos que de manera insuficiente por la falta de concreción, al imponer a la comisión el deber de irrogar una pena proporcionada a la gravedad del delito. Pero es el presunto delincuente quien queda legalmente desprotegido y, por tanto, seriamente perjudicado por la ausencia de tipificación ${ }^{30}$.

La sanción penal, que por sus consecuencias personales y sociales requiere una regulación precisa y clara, se encuentra tratada en la ley de forma indeterminada e imprecisa. Establecer una pena sin legislar su contenido y proceso de aplicación es dejar en manos del Poder Ejecutivo la constitución, juicio e imposición de la pena, por lo que quedan al descubierto exigencias de verdadera importancia como las propias de la división de funciones, tan necesaria para evitar el riesgo de la arbitrariedad. Asimismo, quedan sin respaldo legal principios nacidos para proteger la dignidad de la persona humana, como son el principio de legalidad - entendido en nuestro caso según las características propias del ordenamiento canónico- o el principio de garantía.

La redacción de la norma penal parece estar más influenciada por una concepción moralista que jurídica de la defensa de la ley.

Cuestión muy distinta es la defensa del orden jurídico. Aquí se resuelve un conflicto humano y terreno cuya solución ha de estar iluminada por las exigencias de la virtud de la justicia que inciden también en el juez, obligándole a comportarse según derecho, es decir, según normas positivas de control ${ }^{31}$.

Conforme a la instrucción antes citada, están cubiertos por el secreto pontificio:

4) Las denuncias extrajudiciales de delitos contra la fe y las costumbres, y de delitos perpetrados contra el sacramento de la penitencia, así como también el proceso y las decisiones que se refieren a tales denuncias, haciendo siempre salvedad el derecho de aquel que ha sido denunciado a la autoridad de conocer la denuncia, si ello fuese necesario para su defensa. El nombre del denunciante será lícito hacerlo conocer solo cuando a la autoridad parezca oportuno que el denunciado y el denunciante comparezcan juntos.

30 Ibid, 344 .

31 Ibid., $35^{\circ}$. 
Con mayor precisión, las Normae de delictis Congregationi pro Doctrina Fidei reservatis seu Normae de delictis contra fidemnecnon de gravioribus delictis, del 21 de mayo de $2010^{32}$, establecen que: "Los delitos más graves reservados a la Congregación para la Doctrina de la Fe se persiguen en un proceso judicial" (artículo 21, párrafo 1). Por lo que "Las causas de este género están sujetas al secreto pontificio. [...] Quien viola el secreto o, por dolo o negligencia grave, provoca otro daño al acusado o a los testigos, a instancia de la parte afectada o de oficio, sea castigado por el Turno Superior con una pena adecuada" (artículo 30).

El secreto pontificio también viene explicado en el documento de la Congregación para la Doctrina de la Fe, titulado "Para promover y custodiar la fe: Del Santo Oficio a la Congregación para la Doctrina de la Fe", cuando explica que: "La mayor parte de los asuntos tratados por la Congregación para la Doctrina de la Fe están sometidos, por razón de su naturaleza especialmente delicada, al secreto pontificio. Instituido para sustituir al antiguo secreto del Santo Oficio, el secreto pontificio es una forma de secreto, confirmado con juramento, que se hace necesario para la tutela de las causas y de las grandes decisiones que tengan mucha importancia para la vida de la Iglesia, así como para custodiar a las personas obligadas a conservarlo". Había sido antes regulado por una instrucción especial de la Secretaría de Estado del 24 de junio de 1968, pero fue modificado de nuevo a través de un posterior instructio especial de la misma Secretaría de Estado, aprobado por Pablo VI ex audientia el 4 de febrero de 1974. Su violación culposa comporta las sanciones previstas por el Regolamento Generale della Curia Romana (artículo 36 sección 2, y artículo 76 sección 1 , numeral 3$)^{33}$.

En la "Constitución Apostólica Pastor Bonus de S.S. Juan Pablo II sobre la Curia Romana" ${ }^{34}$, el artículo 48 prescribe que "es función propia de la Congregación de la Doctrina de la Fe promover y tutelar la doctrina sobre la fe y las costumbres en todo el orbe católico; por lo tanto, es competencia suya lo que de cualquier modo se refiere a esa materia”. A su vez, el artículo 52 atribuye a la referida congregación examinar "los delitos cometidos contra la fe y también los delitos más graves cometidos contra la moral o en la celebración de los sacramentos, que le sean denunciados y, en caso necesario, procede a declarar o imponer sanciones canónicas a tenor del derecho, tanto común como propio”.

32 AAS IO2 (2010), 4 I9-434.

33 "Para promover y custodiar la fe", La Santa Sede, recuperado el ro de diciembre de 20 I8 de http:/www.vatican.va/roman_curia/congregations/cfaith/storia/documents/rc_con_cfaith_ storia 20I503Ig promuovere-custodire-fede sp.html.

34 “Constitución Apostólica Pastor Bonus", La Santa Sede, recuperado de http://w2.vatican.va/ content/john-paul-ii/es/apost constitutions/documents/hf jp-ii apc Ig880628 pastor-bonus-index.html. 
De los textos comentados se deduce que, producida la incautación de antecedentes por organismos estatales, no hay lugar a sanciones para los obligados al secreto.

Cabría preguntarse si la entrega de información sometida al secreto pontificio por una persona obligada a este, pero respondiendo a una decisión de los órganos estatales habilitados para intervenir en el proceso penal, podría ser sancionada por la autoridad eclesiástica, toda vez que no resulta propiamente voluntaria, o al menos no espontánea.

\subsection{Interpretación y práctica conocida del secreto pontificio}

La Congregación de la Doctrina de la Fe considera, en el ejercicio de sus competencias, que la investigación previa de los delitos de su competencia y que aún no le son sometidos se encuentra sujeta al secreto pontificio.

Al respecto, conviene tener presente que al tiempo de promulgarse las nuevas "Normas sobre los delitos más graves" ${ }^{35}$, el vocero de la Santa Sede, padre Federico Lombardi, publicó una nota explicativa ${ }^{36}$, en la que encontramos algunos puntos de interés para este informe:

Se vuelve a proponer la normativa sobre la confidencialidad de los procesos para tutelar la dignidad de todas las personas implicadas. Un punto al que no se hace referencia, aunque a menudo es objeto de discusión en estos tiempos, tiene que ver con la colaboración con las autoridades civiles. Hay que tener en cuenta que las normas que se publican ahora forman parte del reglamento penal canónico, en sí completo y plenamente distinto del de los Estados. En este contexto se puede recordar, sin embargo, la "Guía para la comprensión de los procedimientos...", publicada en el sito de la Santa Sede.

En esta "Guía", la indicación: "Deben seguirse siempre las disposiciones de la ley civil en materia de información de delitos a las autoridades competentes", se ha incluido en la sección dedicada a los "Procedimientos preliminares". Esto significa que en la praxis propuesta por la Congregación para la Doctrina de la Fe es necesario adecuarse desde el primer momento a las disposiciones de ley vigentes en los diversos países y no a lo largo del procedimiento canónico o sucesivamente” ${ }^{37}$.

35 “Normas sustanciales", La Santa Sede, recuperado de http://www.vatican.va/resources/resources_norme_sp.html.

36 Federico Lombardi, "El significado de la publicación de las nuevas 'Normas sobre los delitos más graves'”, La Santa Sede, recuperado de http://www.vatican.va/resources/resources_lombardi-nota-norme sp.html.

37 "Guía para comprender los procedimientos fundamentales de la Congregación para la Doctrina de la Fe (CDF) cuando se trata de las acusaciones de abusos sexuales", La Santa Sede, recuperado de http://www.vatican.va/resources/resources_guide-CDF-procedures_sp.html 
¿La adecuación supone que se excluyen del secreto pontificio algunas informaciones de los procesos, en razón de la colaboración con la justicia civil?

Adicionalmente, nos parece que los textos eclesiásticos relativos al secreto pontificio ofrecen numerosas dificultades para su interpretación y aplicación. Así, cabría preguntarse si la obligación de secreto se aplica también a la víctima que denuncia los hechos, o al imputado, porque la respuesta afirmativa llevaría al absurdo de privarla de la disposición de su propio relato vital.

Iǵual situación se plantea respecto de los testigos que intervengan. ¿Podría proporcionarse información de la declaración de un testigo a quien ha sido aludido en esta y comparece como testigo en la investigación?

Por otra parte, en Chile, dos clérigos canonistas que tuvieron a su cargo investigaciones previas de abusos sexuales refirieron a medios de comunicación hechos, actuaciones y circunstancias relativos a estos, así como las decisiones adoptadas por el ordinario eclesiástico del lugarar ${ }^{38}$.

Además, las diócesis y congregaciones religiosas informan habitualmente, a través del sitio web de la Conferencia Episcopal de Chile, sobre el inicio y conclusión de investigaciones previas, así como su envío a la Congregación de la Doctrina de la Fe e incluso la decisión de esta ${ }^{39}$.

En ninguno de estos casos hay noticia de que aquellos que proporcionaron información sobre los delicta graviora fueran sancionados o amonestados por la autoridad eclesiástica. En el mismo sentido de problematizar el alcance del secreto pontificio, resultan de interés

38 Se trata de los clérigos Eliseo Escudero (Gustavo Villarrubia y Juan Andrés Guzmán, "Habla primer investigador eclesiástico de Karadima: “El caso me daba asco'”, Ciper Chile, I de diciembre de 20I2, recuperado de https://ciperchile.cl/20I0/I2/oI/habla-primer-investigador-eclesiastico-de-karadima-\%E2\%80\%gCel-caso-me-daba-asco\%E2\%80\%gD/) y Marcelo Gidi (Martín Romero, "Sacerdote que investigó las denuncias contra monseñor Precht: 'Muchos se sorprendían cuando yo los contactaba'”, La Segunda, 29 de junio de 2or2, recuperado de http://www.lasegunda.com/Noticias/Nacional/20I2/06/759762/marcelo-gidi-el-sacerdote-que-investigo-las-denuncias-contra-monsenor-precht-muchos-se-sorprendian-cuando-yo-los-contactaba).

39 Cfr. El sitio de noticias de Iglesia.cl, disponible en http://www.iglesia.cl/noticias.php, y “Sentencias ejecutoriadas condenatorias en ámbito civil por delitos contra menores de edad cometidos por personas que eran clérigos al momento de la comisión del delito", Iglesia.cl, $3^{\mathrm{I}}$ de octubre de 20I8, recuperado de http://www.iglesia.cl/prevenirabusos/Clerigos_sentencias_20I8I03I.pdf. 
las respuestas en una entrevista de prensa de la doctora en derecho canónico Ana María Celis (presidenta del Consejo Nacional para la Prevención de Abusos), respecto de la información susceptible de ser entregada por la Iglesia. Ante la pregunta "¿hasta dónde está dispuesta la Iglesia a entregar información a la justicia civil?”, Celis responde:

Si la persona recurre a la Iglesia y al mismo tiempo a Fiscalía, se da curso a ambas investigaciones. Pero si la persona manifiesta en la investigación canónica que requiere total confidencialidad, no corresponde a la Iglesia transgredir la intimidad de quien ya fue vulnerado. Sí debe informársele que es su derecho acudir a Fiscalía e incluso instar a hacerlo, debiendo dejarse constancia en el expediente canónico. En adelante se le pedirá que concurra directamente al fiscal preferente que el Ministerio Público haya dispuesto. Ahora bien, si se recibe un requerimiento por parte de Fiscalía, se espera que se señale no solo el número de la causa, sino a lo menos el imputado y las materias que se requieren. De hecho, monseñor Scicluna nos contó de su reunión con miembros de la Fiscalía y nos explicó cómo entendía que debían seguirse los procedimientos para esta colaboración. Si así fuere, no veo dificultad en que se señale quién es el clérigo denunciado; años y lugar de ocurrencia de los hechos; señalar solo genéricamente a las víctimas; si los hechos corresponden a una o más personas, etc. También, si consta, puede indicarse si los denunciantes y / víctimas han hecho denuncia en la Fiscalía o tienen intención de hacerlo o, por el contrario, han manifestado su interés en que no se conozca su identidad; así como indicar la existencia de la investigación previa (inicio y término de la misma) y si se decretaron o no medidas cautelares; indicar si en el caso se inició o no un proceso -y, en su caso, si este es administrativo o judicial-. Además, se puede señalar si el denunciado solicitó la pérdida del estado clerical y si la obtuvo; así como también si se archivó, absolvió o condenó al clérigo denunciado, señalando en el último caso la sanción establecida y, por supuesto, el estado actual de la causa.

Todo ello no vulnera la confidencialidad solicitada por la víctima y, al mismo tiempo, permite que la Fiscalía tome conocimiento de los hechos que no han sido denunciados en esa sede $\mathrm{e}^{40}$.

Recientemente se publicó el documento titulado "Declaración, decisiones y compromisos de los obispos de la Conferencia Episcopal de Chile”, que corresponde a las conclusiones de la 116. ${ }^{a}$ Asamblea Plenaria Extraordinaria del 3 de agosto de 2018. En dicho documento se consignan las siguientes decisiones:

40 María Soledad Vial, “'Es una imputación muy grave confundir encubrimiento con no denunciar, menos cuando la víctima ha pedido confidencialidad', Economía y Negocios, 22 de julio de 2018 , recuperado de http://www.economiaynegocios.cl/noticias/noticias.asp?id=,8970I. 
1. Incluiremos un anexo a las líneas guía "Cuidado y esperanza", norma que rige a todas las diócesis del país, relativo a la plena voluntad de colaborar con el Ministerio Público en la entrega de los antecedentes sobre abuso sexual a menores de edad, resguardando los nombres de denunciantes y víctimas que expresamente soliciten reserva de su identidad. El texto de dicho anexo se dará a conocer apenas se formalice el acuerdo de colaboración con la Fiscalía Nacional que trabaja un equipo jurídico en representación de la Conferencia Episcopal de Chile.

2. A contar de esta fecha, daremos a conocer públicamente toda investigación previa sobre presunto abuso sexual de menores de edad realizada en nuestras jurisdicciones. Lo mismo solicitamos a los superiores de congregaciones religiosas.

Del mismo modo, las instancias del Estado, judiciales, políticas y sociales, están también llamadas a cumplir, desde cada uno de sus ámbitos, la misión de velar por el cuidado de niños, niñas y adolescentes y de buscar legislaciones más adecuadas para castigar el abuso y promover su prevención. Desde la Iglesia, cuentan con toda nuestra disposición $n^{41}$.

De acuerdo con este documento, se informará a la opinión pública de aspectos protegidos por el secreto pontificio, como es la realización de una investigación previa, sin que sepamos de una dispensa o derogación de la obligación de secreto en favor de Chile.

A su vez, el Consejo de Prevención de Abusos y Acompañamiento de Víctimas ${ }^{42}$ ha propuesto un formulario de recepción de denuncia y consentimiento informado, en el que se lee:

2.9) En relación con la colaboración con el Ministerio Público, en caso de ser requerido de información, la autoridad eclesiástica competente entregará toda aquella información conducente al esclarecimiento de los hechos en ámbito estatal, considerando en todo caso, el derecho propio y si el denunciante o víctima solicitó expresamente dicha confidencialidad. Sin embargo, dicha reserva es sin perjuicio de las facultades de la Santa Sede y de la eventual intervención del Ministerio Público o de los Tribunales de Justicia del Estado de Chile, en el marco de una investigación o proceso penal.

41 Los Obispos de la Conferencia Episcopal de Chile, "Declaración, decisiones y compromisos de los obispos de la Conferencia Episcopal de Chile”, Iglesia.cl, 3 de agosto de 20I8, recuperado de http://www.iglesia.cl/4520-declaracion-decisiones-y-compromisos-de-los-obispos-de-la-conferencia-episcopal-de-chile.htm.

42 El Consejo es un organismo asesor de la Conferencia Episcopal, creado en 20 Ir para "orientar y dirigir políticas de prevención sobre abusos sexuales a menores de edad y ayuda a las víctimas" (Cfr. "Prevención de abusos", Iglesia.cl, recuperado de http://www.iglesia.cl/prevenirabusos/ index.php). 
2.10) Para el evento de la ocurrencia de medidas intrusivas (por ejemplo, registro e incautación) por parte del Ministerio Público, la autoridad eclesiástica o un delegado suyo procurará dar noticia dentro de las 24 horas siguientes al denunciante o víctima de los archivos que han sido incautados.

\section{OBLIGACIONES QUE IMPONE EL DERECHO INTERNACIONAL DE LOS DERECHOS HUMANOS}

Si bien este aspecto de informe ha sido expresamente excluido por el solicitante, al menos quisiéramos consignar que la Constitución de 1980 y el derecho internacional de los derechos humanos consagran mandatos y obligaciones para el Estado de Chile respecto del abuso sexual de menores, en el sentido de prevenirlo, castigarlo y procurar su reparación.

En este sentido, el Comité sobre los Derechos del Niño ha señalado expresamente los ámbitos y materias en los que nuestro país debe avanzar ${ }^{23}$.

La Santa Sede, por su parte, ha debido informar sobre su conducta en cuanto a la prevención, sanción y reparación ante Naciones Unidas, todo lo cual puede consultarse en los documentos emitidos por ambas partes, en los que constan en detalle tanto las fuentes de dichas obligaciones como su estado de cumplimiento ${ }^{\text {4h. }}$.

\section{INFORMACIÓN ECLESIAL REQUERIDA POR LOS TRIBUNALES ESTATALES}

\section{I. Antecedentes}

De acuerdo con información oficiosa obtenida sobre la situación nacional, los procesos iniciados en razón de hechos considerados como abuso sexual históricamente afectarían aproximadamente a 275 personas investigadas. A su vez, las víctimas sumarían 407 per-

43 “Informes ante el Comité de los Derechos del Niño", Unicef, recuperado el 26 de diciembre de 2018 de https://unicef.cl/web/informes-comite/.

44 "Examen de los informes presentados por los Estados partes en virtud del artículo i2, párrafo I, del Protocolo facultativo relativo a la venta de niños, la prostitución infantil y la utilización de niños en la pornografía”, Naciones Unidas, 8 de noviembre de 2012 , recuperado de https:// tbinternet.ohchr.org/ layouts/I5/treatybodyexternal/Download.aspx?symbolno=CRC\%2fC\%2fOPSC\%2fVAT\%2fi\&Lang=es; "Examen de los informes presentados por los Estados partes en virtud del párrafo I del artículo 8 del Protocolo Facultativo de la Convención sobre los Derechos del Niño relativo a la participación de niños en los conflictos armados”, Naciones Unidas, 22 de octubre de 20I2, recuperado de https://tbinternet.ohchr.org/_layouts/I5/treatybodyexternal/Download.aspx?symbolno=CRC\%2fC\%2fOPAC\%2fVAT\%2fi\&Lang=es. 
sonas, y causas abiertas en razón de estos hechos serían 260. Finalmente, en la actualidad existirían 192 personas investigadas y 246 personas afectadas en un total de 141 causas.

\subsection{Relaciones entre los tribunales civiles y eclesiásticos}

Como ya se ha dicho, el derecho chileno reconoce la personalidad jurídica de la Iglesia católica y la recepciona con su estructura y ordenamiento interno (canónico). Sin embargo, por no existir un acuerdo entre el Estado de Chile y la Santa Sede, las relaciones entre los tribunales del fuero civil y canónico carecen de regulación especial ${ }^{45}$.

Así, actualmente en Chile existe duplicidad de celebraciones matrimoniales, canónica y $\operatorname{civi}^{46}$, y el derecho chileno se refiere al matrimonio canónico para aspectos muy puntuales, mientras que no reconoce efectos a las sentencias canónicas frente al matrimonio celebrado también de manera civil ${ }^{27}$.

Algo similar podría afirmarse respecto de las investigaciones previas, que no se encuentran encomendadas a un tribunal por la autoridad eclesiástica y que podrían, eventualmente, dar origen y formar parte de un proceso judicial posterior.

Desde el punto de vista de la legislación civil nacional, aparece discutible considerar que la facultad de imperio del tribunal ordinario le otorgaría jurisdicción para solicitar antecedentes a la autoridad eclesiástica tratándose de los llamados delicta graviora, ya que, como bien lo expresaba el Código Orgánico de Tribunales, a estos les "corresponderá el conocimiento de todos los asuntos judiciales que se promuevan en el orden temporal dentro del territorio de la república” (artículo 5, versión original).

A través de los medios de comunicación se ha conocido la preocupación de las autoridades vaticanas respecto de la incautación indiscriminada de documentos, incluyendo aquellos que recogen testimonios de personas que han pedido expresamente que se respete su confidencialidad o que tratan de materias completamente ajenas a las investigaciones

45 Salvo en los asuntos que han sido regulados por tratados internacionales suscritos, ratificados y vigentes para ambas partes.

46 Aunque también se contempla la posibilidad de que el matrimonio religioso sea reconocido y tenga efectos civiles; sin embargo, los requisitos suponen prácticamente una segunda celebración, ahora civil, por lo que no ha sido utilizado en forma significativa.

47 Aun cuando dichas sentencias han sido admitidas como medio probatorio en las causas civiles de divorcio. 
en curso. Al respecto, habría que decir que las personas naturales o jurídicas afectadas por tales procedimientos pueden objetarlos, recurriendo al derecho común en materia procesal penal.

\subsection{Argumentos de la Iglesia católica para rechazar la entrega de antecedentes a la justicia civil}

Forma parte de la actividad diplomática el envío de exhortos y solicitudes de asistencia en materia penal dirigidos a la Santa Sede por conducto del Ministerio de Relaciones Exteriores. Esta práctica supone el reconocimiento del estatus jurídico de la Santa Sede, y podría considerarse también un reconocimiento tanto de la competencia jurisdiccional propia de la Iglesia católica, como del secreto pontificio mismo.

La entrega no autorizada de información o documentos por la competente autoridad eclesiástica constituye un delito canónico en el propio ordenamiento eclesial reconocido por el Estado de Chile.

Los documentos asociados a la investigación de los abusos sexuales cometidos por clérigos en contra de niños y niñas se encuentran protegidos por el secreto pontificio, y los órganos del Estado han reconocido expresamente en sus decisiones administrativas y judiciales que el estatuto jurídico reconocido a la Iglesia católica en Chile incluye esta institución. No obstante, un testigo podría autorizar, al momento de prestar su declaración o posteriormente, a la competente autoridad eclesiástica para entregar su testimonio a los tribunales, o bien podría prestar su declaración nuevamente en Fiscalía, en forma espontánea o cuando se produce la solicitud ${ }^{28}$.

Por otra parte, si el testigo o víctima no ha recurrido a la justicia civil, ni hecho público su testimonio, habría que entender que su voluntad es que la Iglesia lo conserve bajo reserva. Tratándose de documentación relativa a materias del todo ajenas a la investigación, como podrían ser las causas de nulidad matrimonial, su incautación resultaría improcedente de acuerdo con las reglas generales del derecho procesal penal chileno.

\subsection{Antecedentes judiciales: Caso Karadima ${ }^{29}$}

El arzobispo de Santiago, Francisco Javier Errázuriz, en respuesta a la solicitud formulada por un tribunal para que se le entregue una copia de la investigación eclesiástica sobre la conducta del presbítero Karadima, respondió:

48 En la atención de víctimas de abuso sexual se desaconseja someterlas a sucesivos interrogatorios en los que deba relatar nuevamente el contenido de la denuncia, ya que estos constituyen una revictimización de ellas y profundiza el daño que sufrieron en el pasado.

49 Cfr. las causas rol 10.456-20I5 y 2.96r-20II del $34^{\circ}{ }^{\circ}$ Juzgado del Crimen de Santiago; rol 20.16920I5 civil ministro de fuero de la Corte de Apelaciones; y ruc o80II94893-7 y ogoog6ro62-3. 
Junto con saludar, la presente tiene por objeto informarle a usted la imposibilidad de este obispo de entregar la información solicitada por el oficio antes mencionado, dado el secreto pontificio que recae sobre dicha investigación. Las denuncias y las declaraciones que se reciban por parte de la Iglesia en el caso de delitos cometidos por miembros de esta son secretas, con el objetivo de salvaguardar el buen nombre de las personas; proteger a las víctimas; y obtener todas las informaciones que sean necesarias. Esta obligación para los jueces, ayudantes del tribunal y toda otra persona que por razón de su cargo haya conocido dichos antecedentes, se encuentra establecida en la normativa canónica, que rige a nuestra Iǵlesia católica (canon 1.455, Código Canónico). A mayor abundamiento, las investigaciones canónicas por delitos graves, dentro de los que se encuentran los ilícitos de carácter sexual como el del presente caso, están sujetas al secreto pontificio y se sanciona con una pena a quien divulgue dicha información (artículo 30, Normae de Gravioribus Delictis). De hecho, el ordenamiento jurídico chileno reconoce la especial naturaleza de la información entregada a miembros de la Iglesia, consagrando expresamente la facultad de abstención de declarar o entregar información que se hubiere confiado a quienes por su estado, profesión o función legal tengan el deber de guardar secreto, lo que sucede en el presente caso (artículo 303, Código Procesal Penal).

\section{COMPROMISO DE COLABORACIÓN DE LA IGLESIA CATÓLICA EN LA INVESTIGACIÓN Y SANCIÓN DE LOS DELITOS DE ABUSO SEXUAL DE MENORES}

\section{I. De la Santa Sede}

En junio de 2010, Benedicto XVI hizo llegar un mensaje al arzobispo de Malinas-Bruselas, monseñor André Joseph Léonard, tras el brutal registro de las autoridades belgas al arzobispado y la catedral de la diócesis primada belga, en el marco de una investigación por abusos sexuales por parte del clero, en los términos siguientes:

Deseo expresarle, querido hermano en el episcopado, así como a todos los obispos de Bélgica, mi proximidad y mi solidaridad en este momento de tristeza, en el que, con ciertas maneras sorprendentes y deplorables, se han realizado las investigaciones incluso en la catedral de Malinas y en los locales donde el episcopado belga estaba reunido en sesión plenaria. Durante esta reunión, debían tratarse, entre otros, aspectos relacionados con el abuso a menores por parte de miembros del clero. Yo mismo he repetido en numerosas ocasiones que estos graves hechos deben ser tratados por el orden civil y por el orden canónico en el respeto recíproco de la especificidad y de la autonomía de cada uno. En este sentido, deseo que la justicia siga su curso garantizando el derecho de las personas y las instituciones, en el respeto a las víctimas, en el reconocimiento sin prejuicios de los que se comprometen a colaborar con ella y en el rechazo de todo lo que pudiera oscurecer los nobles deberes que le son asignados ${ }^{50}$.

50 Oficina de prensa de la Santa Sede, 20 de junio de 2010. 
Particular relevancia, en este sentido, cabe otorgar al documento que el papa Francisco entregó a los obispos en Roma el 15 de mayo de $2018^{51}$, en el que, refiriéndose a la situación de los abusos sexuales cometidos por clérigos en Chile, decía en la nota a pie de página 25:

Me gustaría detenerme en tres situaciones que se desprenden del informe de la "Misión especial" (Scicluna): 1) La investigación demuestra que existen graves defectos en el modo de gestionar los casos de delicta graviora que corroboran algunos datos preocupantes que comenzaron a saberse en algunos dicasterios romanos. Especialmente en el modo de recibir las denuncias o notitiae crimini, pues en no pocos casos han sido calificados muy superficialmente como inverosímiles, lo que eran graves indicios de un efectivo delito. Durante la visita se ha constado también la existencia de presuntos delitos investigados solo a destiempo o incluso nunca investidos [sic], con el consiguiente escándalo para los denunciantes y para todos aquellos que conocían las presuntas víctimas, familias, amigos, comunidades parroquiales. En otros casos, se ha constado la existencia de gravísimas negligencias en la protección de los niños/as y de los niños/as vulnerables por parte de los obispos y superiores religiosos, los cuales tienen una especial responsabilidad en la tarea de proteger al pueblo de Dios. 2) Otra circunstancia análoga que me ha causado perplejidad y vergüenza ha sido la lectura de las declaraciones que certifican presiones ejercidas sobre aquellos que debían llevar adelante la instrucción de los procesos penales o incluso la destrucción de documentos comprometedores por parte de encargados de archivos eclesiásticos, evidenciando así una absoluta falta de respeto por el procedimiento canónico y, más aún, unas prácticas reprobables que deberán ser evitadas en el futuro.

Luego, el 31 de mayo, en carta a los fieles de la Iglesia chilena, les decía:

Hoy sabemos que la mejor palabra que podamos dar frente al dolor causado es el compromiso para la conversión personal, comunitaria y social que aprenda a escuchar y cuidar especialmente a los más vulnerables. Urge, por tanto, generar espacios donde la cultura del abuso y del encubrimiento no sea el esquema dominante; donde no se confunda una actitud crítica y cuestionadora con traición. Esto nos tiene que impulsar como Iglesia a buscar con humildad a todos los actores

51 Véase "La transcripción completa del documento reservado que el Papa entregó a los obispos chilenos", Teler3.cl, I7 de mayo de 20I8, recuperado el 28 de diciembre de 2018 de https:// www.trz.cl/noticia/nacional/la-transcripcion-completa-del-documento-reservado-papa-entrego-obispos-chilenos. Según la prensa, el documento fue filtrado desde la misma Santa Sede, y su texto no ha sido desautorizado. 
que configuran la realidad social y promover instancias de diálogo y constructiva confrontación para caminar hacia una cultura del cuidado y protección ${ }^{52}$.

Finalmente, el 21 de diciembre de 2018, dirigiéndose al personal de la Curia Romana, el papa Francisco les decía: "A los que abusan de los menores querría decirles: convertíos y entregaos a la justicia humana, y preparaos a la justicia divina, recordando las palabras de Cristo: 'Al que escandalice a uno de estos pequeños que creen en mí, más le valdría que le colgasen una piedra de molino al cuello y lo arrojasen al fondo del mar. ¡Ay del mundo por los escándalos」 Es inevitable que sucedan escándalos, ;pero ay del hombre por el que viene el escándalo!"”33.

\subsection{De la Conferencia Episcopal de Chile}

A las mencionadas declaraciones pueden sumarse las efectuadas por la Conferencia Episcopal de Chile, incluso en un documento con carácter de ley eclesial, como son las llamadas líneas guía para tratar los casos de abusos sexuales a menores de edad aprobadas para su publicación en la 109. ${ }^{a}$ Asamblea Plenaria en abril de 2015.

El referido documento, en el numeral 31, señala: "Dado que las conductas de significación sexual en contra de menores de edad, no constituyen solo un delito canónico, sino también un crimen perseguido por la autoridad civil (Congregación para la Doctrina de la Fe, Carta Circular del 3 de mayo de 2011, I, e), es oportuno subrayar que la Iglesia respeta el ordenamiento estatal vigente y, por tanto, colabora en la búsqueda de la verdad, también en sede civil, con el propósito de favorecer el esclarecimiento de estos hechos y su prevención".

En el documento, el episcopado nacional ha expresado pública y unánimemente su rechazo a estas conductas ${ }^{54}$ y el compromiso de colaboración afirmando que "considera un deber la colaboración con la sociedad y sus autoridades para que el derecho y la justicia

52 Francisco I, "Carta del santo padre Francisco al pueblo de Dios que peregrina en chile”, La Santa Sede, recuperado el 28 de diciembre de 2018 de http://w2.vatican.va/content/francesco/es/ letters/20I8/documents/papa-francesco 20I8053I lettera-popolodidio-cile.html.

53 Francisco I, "Discurso del santo padre Francisco", La Santa Sede, recuperado el 28 de diciembre de 2018 de http://w2.vatican.va/content/francesco/es/speeches/20I8/december/documents/ papa-francesco_20I8I22I_curia-romana.html.

54 Alejandro Goic Karmelic, obispo de Rancagua, presidente del Consejo Nacional de Prevención de Abusos y Acompañamiento de Víctimas de la Conferencia Episcopal de Chile, dice: "Miramos hoy a la Iglesia samaritana de ayer, voz de los sin voz, refugio de vulnerados y vulnerables, la que abría sus puertas para ofrecerles amparo y protección, la que desde su fuerza moral emergía como referente natural para grandes acuerdos nacionales. Y nos preguntamos: ¿qué nos ocurrió?, ¿cómo pudimos llegar al contrasentido de nuestra misión que significa el daño a menores?, ¿cómo recuperar nuestra debilitada credibilidad de hoy?”. 
sean una realidad en toda la nación, incluso al interior de las comunidades de la Iglesia católica", y que "respeta el ordenamiento estatal vigente y, por tanto, colabora en la búsqueda de la verdad, también en sede civil, con el propósito de favorecer el esclarecimiento de estos hechos y su prevención”.

Como mencionamos, recientemente se publicó el documento "Declaración, decisiones y compromisos de los obispos de la Conferencia Episcopal de Chile", que corresponde a las conclusiones de la 116. ${ }^{a}$ Asamblea Plenaria Extraordinaria del 3 de agosto de 2018.

En dicho documento se consignan las siguientes decisiones:

1. Incluiremos un anexo a las líneas guía "Cuidado y esperanza", norma que rige a todas las diócesis del país, relativo a la plena voluntad de colaborar con el Ministerio Público en la entrega de los antecedentes sobre abuso sexual a menores de $e d a d^{55}$, resguardando los nombres de denunciantes y víctimas que expresamente soliciten reserva de su identidad. El texto de dicho anexo se dará a conocer apenas se formalice el acuerdo de colaboración con la Fiscalía Nacional que trabaja un equipo jurídico en representación de la Conferencia Episcopal de Chile.

2. A contar de esta fecha, daremos a conocer públicamente toda investigación previa sobre presunto abuso sexual de menores de edad realizada en nuestras jurisdicciones. Lo mismo solicitamos a los superiores de congregaciones religiosas.

Del mismo modo, las instancias del Estado, judiciales, políticas y sociales, están también llamadas a cumplir, desde cada uno de sus ámbitos, la misión de velar por el cuidado de niños, niñas y adolescentes y de buscar legislaciones más adecuadas para castigar el abuso y promover su prevención. Desde la Iglesia, cuentan con toda nuestra disposición.

2.3. Siempre se debe respetar e incluso alentar que las víctimas o sobrevivientes ejerzan el derecho de actuar según su conciencia en cuanto a la denuncia ante las autoridades estatales, sea que se trate de denuncias sobre hechos ya prescritos o de hechos recientes. No corresponde presionar moralmente a las víctimas para que se abstengan de denunciar.

2.9. En relación con la colaboración con el Ministerio Público, en caso de ser requerido de información, la autoridad eclesiástica competente entregará toda

55 Después de entregado el presente informe, se publicó un acuerdo de colaboración entre el episcopado católico y la Fiscalía Nacional, el que al cabo de algunos días fue revocado de común acuerdo ante las críticas de las víctimas de abuso sexual y organizaciones vinculadas. 
aquella información conducente al esclarecimiento de los hechos en ámbito estatal, considerando en todo caso, el derecho propio y si el denunciante o víctima solicitó expresamente dicha confidencialidad. Sin embargo, dicha reserva es sin perjuicio de las facultades de la Santa Sede y de la eventual intervención del Ministerio Público o de los Tribunales de Justicia del Estado de Chile, en el marco de una investigación o proceso penal ${ }^{56}$.

\section{CONCLUSIONES}

Ante el derecho chileno, la Iǵlesia católica es una persona jurídica de derecho público. Respecto de la Santa Sede, podríamos agregar de derecho internacional.

El reconocimiento de la personalidad jurídica se encuentra asociado también a su derecho propio. Esto es verificable no solo en la doctrina y jurisprudencia, sino también en el ejercicio de sus competencias por parte de los órganos del Estado de Chile. El estatus jurídico de la Iglesia católica en Chile la habilita para ejercer una particular jurisdicción respecto de sus miembros que son clérigos cuando ha existido abuso sexual de menores.

En los últimos veinte años encontramos manifestaciones claras del reconocimiento de la mencionada jurisdicción, tanto de parte de los tribunales ordinarios de justicia como de otros órganos del Estado. Considerando que la recepción del derecho interno de la Iglesia católica en ordenamiento chileno no contempla expresamente limitaciones, dicha recepción debe ser interpretada de modo armónico con el resto de los preceptos constitucionales, especialmente armonizándola con el respeto de los derechos fundamentales reconocidos en la Constitución de 1980 y los tratados que versan sobre derechos humanos, ratificados por Chile y que se encuentren vigentes (artículo 5 , inciso segundo).

No obstante lo anterior, la jurisdicción canónica existe sin perjuicio de la potestad del Estado de Chile para investigar y sancionar los delitos cometidos en su territorio, lo que también ha sido reconocido por la Iglesia católica, en cuanto ha puesto en conocimiento de las fiscalías competentes las conductas de personas sometidas a su ordenamiento propio y anima a las víctimas a formular denuncias en el fuero civil.

En cuanto al llamado "secreto pontificio", debe tenerse presente que es obligatorio para las personas sometidas al derecho canónico, quienes arriesgan sanciones, establecidas en el mismo derecho, en caso de vulneración. Además, los tribunales ordinarios de justicia han interpretado que el mencionado secreto forma parte del derecho propio de una persona jurídica de derecho público, reconocida por el Estado de Chile.

56 Los Obispos de la Conferencia Episcopal de Chile, "Declaración”. 
Es por este motivo ${ }^{57}$ que, según informa la prensa, el Estado chileno ha solicitado al Ministerio de Relaciones Exteriores que requiera documentos e información, vía exhorto internacional, a la Santa Sede.

Esta reserva de información y documentos que impone el ordenamiento canónico no es absoluta en las relaciones de la Iglesia con la sociedad, o de la Santa Sede con los Estados, puesto que, como hemos visto, existe una práctica de informar a la opinión pública sobre las llamadas investigaciones previas, e incluso se ha puesto a disposición de los tribunales la documentación en poder de la Iglesia ${ }^{58}$.

Considerando que la recepción del derecho propio de la Iglesia católica representa un complejo desafío interpretativo, en cuanto pareciera oponer normas de rango constitucional entre sí, podría avanzarse la hipótesis de que dicho secreto obliga a quienes toman conocimiento de él prohibiéndoles la revelación voluntaria o espontánea.

Sin embargo, el referido secreto no puede considerarse un obstáculo para los tribunales de justicia en la investigación y sanción del abuso sexual de menores, puesto que la jurisdicción que se les concede no solo es exclusiva, sino que está acompañada de la facultad de imperio (artículo 76 de la Constitución de 1980).

Las excepciones y limitaciones que se consideren aplicables al secreto pontificio por el Estado de Chile deberían ser reconocidas y aceptadas por la Santa Sede. En caso contrario, la oposición de la autoridad eclesiástica supondrá un impedimento para obtener la información y, de aplicarse medidas de apremio, un conflicto para el Estado, tanto respecto de la Iglesia local, como eventualmente con la Santa Sede.

Considerando el grave deber moral, religioso y jurídico que el secreto pontificio impone a los católicos, el Estado de Chile podría solicitar a la Sede Apostólica que por ley particular los exonere, previa consulta a las respectivas víctimas, para entregar esta información a los tribunales que conocen de un delito, o de la responsabilidad de oficio asociada a este $^{59}$.

Sin perjuicio del reconocimiento constitucional de la libertad religiosa y del estatuto jurídico de la Iglesia católica, el Estado de Chile ha incorporado a su ordenamiento, con un estatus particular (artículo 5, inciso segundo de la Constitución), los derechos fundamen-

57 Además del hecho de no existir una regulación jurídica para las relaciones entre la autoridad eclesiástica en el ejercicio de la función jurisdiccional y los tribunales estatales, como ya hemos dicho.

58 Tampoco existe información pública en la Iǵlesia de que algunas personas obligadas al secreto pontificio hayan sido sancionadas por la vulneración del sigilo.

59 Se hace presente la necesidad de consultar a un canonista para resolver sobre la viabilidad jurídica y política de las propuestas que exceden el derecho constitucional chileno. 
tales de los niños. La suscripción de varios tratados internacionales supone la obligación internacional y ante el derecho interno de dar protección a los menores y prevenir los hechos que puedan dañarlos, particularmente los delitos contra la indemnidad sexual, junto con investigarlos y sancionarlos.

La Santa Sede, al igual que Chile, es signataria de la Convención Internacional de los Derechos del $\mathrm{Niño}^{60}$ e informa periódicamente de su cumplimiento a Naciones Unidas. Estos deberes estatales, en caso de incumplimiento o negligencia, acarrean responsabilidad tanto en el ámbito interno como internacional, y pueden dar lugar a la persecución de su responsabilidad pecuniaria y ante los órganos internacionales competentes.

Como consecuencia, el Estado de Chile debe cumplir simultáneamente el deber de proteger la libertad religiosa y la protección de los menores respecto del abuso sexual del que puedan ser víctimas. Esto debe considerarse sobre todo al momento de interpretar las normas jurídicas aplicables en la persecución de los delitos cometidos contra niños y niñas, excluyendo aquellas hipótesis en las que se admitan obstáculos que hagan imposible dicha tarea.

En el cumplimiento de sus obligaciones, el Estado de Chile debe contar con la colaboración de la Santa Sede, ya que esta misma, según se ha consignado, ha declarado reiteradas veces su compromiso en tal sentido. Las numerosas declaraciones y documentos de la Santa Sede durante los dos últimos pontificados, así como aquellos emanados de la Conferencia Episcopal de Chile, manifiestan clara y explícitamente la disposición para convenir un modo de colaboración oportuno y eficaz tanto respecto de la prevención como de la sanción de estos delitos.

Así parece ser también la tendencia en España:

La concepción de la justicia camina, claramente, por afirmar que el Estado es competente para juzgar los delitos dentro del ámbito eclesiástico, ya que son ciudadanos españoles quienes sufren las situaciones y quienes las cometen. Por eso mismo, creo que deberíamos aprender a colaborar de un modo más confiado y humilde con la justicia civil. También asumiendo criterios de defensa de los derechos como lo hace la justicia civil. Pero no hemos de olvidar que el camino adoptado por la Santa Sede en su tolerancia cero implica que exista esta colaboración

60 "Conventions on the Rights of the Child", United Nations Treaty Collection, recuperado de https://treaties.un.org/Pages/ViewDetails.aspx?src=TREATY\&mtdsg_no=IV-II\&chapter=,\&clang=_en\#EndDec. 
desde el inicio del proceso, sea canónico o civil. En los últimos casos conocidos la Santa Sede ha autorizado que se entregasen las actuaciones realizadas en la investigación previa ${ }^{61}$.

\section{COMENTARIOS FINALES DEL AUTOR}

De acuerdo con lo expuesto, es previsible que el secreto pontificio no constituirá un motivo de conflicto entre la Santa Sede y el Estado de Chile, ya que, como resulta de la práctica actual, el rigor conceptual ha cedido progresivamente en beneficio de la colaboración con el Estado. En el mismo sentido cabe considerar la insistencia de la Iglesia para animar a las víctimas a denunciar los hechos que se confían a ella también a la fiscalía respectiva. No obstante, la materia del informe evidencia también otros asuntos bilaterales que requieren de instrumentos jurídicos para ser regulados. En tal sentido, la celebración de acuerdo con la Santa Sede ${ }^{62}$ podría ser un medio a explorar para convenir la entrega de información a los tribunales, la obligación de denuncia, etcétera.

De acuerdo con el derecho canónico, la obligación de las autoridades en la Iglesia consiste no solo en prevenir la comisión de abusos sexuales, sino garantizar que quienes se relacionan por encargo suyo con menores y adultos vulnerables tienen el perfil necesario para desempeñar las tareas propias de su ministerio sin causar daño.

En el mencionado acuerdo, entre otras materias, podrían incluirse las siguientes respecto de la Iglesia:

a. El establecimiento de un programa de formación en prevención, exigible a todo el personal que se desempeñe en instituciones eclesiales vinculadas a menores.

b. La obligación, para todas las instituciones antes mencionadas, de requerir la presentación del respectivo certificado de antecedentes y de no encontrarse inhabilitado para trabajar con menores a todo su personal.

c. Establecer un perfil psicológico exigible para quienes se desempeñan en

61 Jesús Rodríguez Torrente, "Proceso penal canónico y colaboración con la justicia estatal en los delitos de abusos sexuales”, en Reforma de los procesos de nulidad y otras novedades legislativas de derecho canónico y eclesiástico del Estado, coord. de Lourdes Ruano Espina y Cristina Guzmán Pérez (Madrid: Dykinson, 20I7), 65.

62 Desde 20I3, la Santa Sede ha firmado o ratificado catorce acuerdos con Estados: Burundi, Cabo Verde, Chad, Hungría, Malta, Camerún, Serbia, Estados Unidos, Italia, República Democrática de Timor Oriental, Palestina, Francia, República Centroafricana y la República Democrática del Congo. 
la formación y cuidado de menores o adultos vulnerables y que excluya a quienes poseen características no apropiadas.

d. Establecer un registro de sanciones canónicas por abuso sexual de menores accesible en los mismos términos que el estatal.

e. Imponer la obligación de denuncia para todos los que desempeñan funciones en contacto con menores y adultos vulnerables, o quienes tienen oficio en la Iglesia, con una sanción agravada cuando por sentencia ejecutoriada se condene al autor de los hechos no denunciados ${ }^{63}$.

f. La organización de un registro público de personas jurídicas, estatutos y autoridades, particularmente de los ministros de culto.

Se sugiere solicitar a la Santa Sede una aclaración legislativa de los efectos del secreto pontificio cuando se refiera a hechos constitutivos de delitos en el fuero civil o a información necesaria para su investigación, sanción y reparación, acorde con las declaraciones papales de colaboración con la justicia, las obligaciones internacionales que ha contraído y reconociendo la colaboración que en la práctica viene prestando a los demás Estados.

63 Como ya decíamos, se ha presentado en la Cámara de Diputados un proyecto de ley para imponer a las autoridades religiosas o eclesiásticas la obligación de denunciar hechos que revistieren caracteres de delito contra menores de edad y personas impedidas de ejercer con autonomía sus derechos, y de que tomaren conocimiento en virtud de sus funciones (Boletín II. $768-07)$. 


\section{BIBLIOGRAFÍA}

- Arias, Juan, "Las normas sobre el secreto pontificio: Sistema de defensa”. Ius Canonicum 14, n. ${ }^{\circ} 2$ (1974): 332-352. Recuperado de http:// dadun.unav.edu/handle/10171/14766.

- Cortínez Castro, René (coordinador), Ana María Celis Brunet y María Elena Pimstein Scroggie, Derecho eclesiástico chileno: Normas concordadas y comentadas. Santiago: Ediciones UC, 2010.

- Del Picó Rubio, Jorge. "Régimen especial de reconocimiento de la personalidad jurídica de derecho público en la Ley 19.638: Marco legal aplicable a las iglesias católica y ortodoxa”. Ius et Praxis 18, n. $^{\circ} 1$ (2012): 37-60. doi: 10.4067/S0718-00122012000100003.

- Rodríguez Torrente, Jesús. "Proceso penal canónico y colaboración con la justicia estatal en los delitos de abusos sexuales". En Reforma de los procesos de nulidad y otras novedades legislativas de derecho canónico y eclesiástico del Estado, coordinado por Lourdes Ruano Espina y Cristina Guzmán Pérez, 23-66. Madrid: Dykinson, 2017.

- Precht Pizarro, Jorge. "La personalidad jurídica de la Iglesia católica y de los entes eclesiásticos católicos ante el derecho del Estado de

Chile”. Revista Chilena de Derecho 16, n. $^{\circ} 3$ (septiembre-diciembre 1989): 683-723. 